\title{
GLUCOSE METABOLISM IN HUMAN ERYTHROCYTES FROM NORMAL AND FAVA BEAN-SENSITIVE SUBJECTS *
}

\author{
By G. FORNAINI, G. LEONCINI, L. LUZZATTO AND G. SEGNI
}

(From the Istituto di Chimica Biologica e Clinica Pediatrica dell'Università di Genova, Genoa, Italy)

(Submitted for publication December 18, 1961 ; accepted March 29, 1962)

Many studies during the last decade have been concerned with the biochemical properties underlying various states of the human red blood cell, including its maturation, aging, and some abnormal conditions.

A considerable amount of work has been devoted particularly to the study of erythrocyte metabolism in the fava bean- and drug-induced hemolytic anemias. Observations were first made by Beutler and his co-workers $(1,2)$ concerning the instability and decreased content of reduced glutathione $(\mathrm{GSH})$ in red cells in drug-induced anemia. Carson (3) and Gross (4) and their colleagues, and Sansone and Segni $(5,6)$ demonstrated glucose-6-phosphate dehydrogenase (G6PD) deficiency in these cells. Further work has since been done in an attempt to find a link between the genetically determined metabolic defect and the hemolytic phenomenon.

Such studies have been concerned mainly with the activity and properties of various enzymes, and some work in this field has been done also in our laboratory $(7-10)$. In the present paper a somewhat different approach is described. Glucose metabolism in fava bean-sensitive versus normal erythrocyte suspensions has been followed by quantitatively estimating the different metabolites that arise from its consumption in vitro. On these transformations, as well as on triose phosphate oxidation by hemolyzed red cells, the action of methylene blue $(\mathrm{Mb})$ has also been studied.

\section{METHODS}

Subjects. Blood was obtained from seven men and two women from Sardinia, five of whom belong to the same

* This work was supported by Grant H 4586 of the United States Public Health Service. Preliminary communications concerning some of the results reported in the present paper have appeared in Boll. Soc. ital. Biol. sper. 1961, 37, 1046, 1048. family. Two of them had experienced acute hemolytic anemia (24 and 16 months ago, respectively) after fava bean ingestion. In all of them red cell G6PD was lacking, reduced glutathione was decreased, the Beutler test (2) was positive, and the reticulocyte count was normal. Normal subjects of both sexes and of approximately corresponding ages were used as controls.

Preparation of red blood cell suspensions. The blood was collected by venipuncture, and heparin added. After centrifugation the plasma and buffy coat were removed by suction, the red blood cells (RBC) were washed thrice

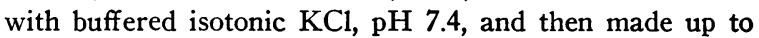
volume. The packed cell volume was determined on this suspension by centrifuging in a hematocrit tube for 60 minutes at $1,200 \times \mathrm{G}$. RBC suspensions were never completely free from leukocytes. The contamination, however, was always less than 0.05 per cent.

Hemolyzed preparations. These were prepared by treating the washed RBC with 2 vol of ice-cold water. The ghosts were removed by centrifuging for 30 minutes at $30,000 \times \mathrm{G}$. The supernatant fluid was then diluted as required. All manipulations were performed at $+2^{\circ} \mathrm{C}$.

Incubation and extraction. In the experiments concerning glucose metabolism in intact $\mathrm{RBC}$, each reaction vessel contained, per milliliter : $10 \mu$ moles of glucose; 30 $\mu$ moles of sodium phosphate buffer, $\mathrm{pH} 7.4 ; 0.43 \mathrm{ml}$ $\mathrm{RBC}$; and where required, $0.038 \mu$ mole of $\mathrm{Mb}$ (unless otherwise stated). After 10 minutes' preincubation at $37^{\circ} \mathrm{C}$ the reaction was started by adding glucose and was incubated at the same temperature with shaking at 80 cycles per minute. At the desired intervals $2.0-\mathrm{ml}$ aliquots of the mixture were added to a centrifuge tube containing $4.0 \mathrm{ml}$ of ice-cold $0.15 \mathrm{M} \mathrm{KCl}$ in $0.005 \mathrm{M}$ $\mathrm{NaF}$ and spun down at once at $+2^{\circ} \mathrm{C}$. The supernatant fluid was gently aspirated, and the RBC were washed twice with the $\mathrm{KCl}-\mathrm{NaF}$ solution, then hemolyzed with 4 vol of cold water, and extracted with trichloroacetic acid (10 per cent final concentration). The clear fluid obtained by filtration was neutralized with $\mathrm{NaOH}$ and made up to volume.

For the experiments with fructose-1,6-diphosphate $(\mathrm{F}-1,6 \mathrm{P})$ the incubation mixture contained per milliter: $3 \mu$ moles of $\mathrm{F}-1,6 \mathrm{P} ; 25 \mu$ moles of $\mathrm{pH} 7.4$ glycylglycine buffer; $15 \mu$ moles of nicotinic amide; $50 \mu$ moles of $\mathrm{Na}_{3} \mathrm{AsO}_{4} ; 3 \mu$ moles of $\mathrm{MgSO}_{4} ; 0.10 \mu$ mole of DPN; $0.1 \mathrm{ml}$ of hemolyzed cells corresponding to $0.03 \mathrm{ml}$ of $\mathrm{RBC}$; and $\mathrm{Mb}$ at the required concentration. After incubation in a water bath at $37^{\circ} \mathrm{C}, 2.0-\mathrm{ml}$ aliquots were 
TABLE I

Metabolite concentrations in erythrocytes from normal and favic human subjects *

\begin{tabular}{|c|c|c|c|c|c|c|c|c|c|}
\hline Subjects & $\begin{array}{l}\text { Glucose-6- } \\
\text { phosphate }\end{array}$ & $\begin{array}{l}\text { Fructose-6- } \\
\text { phosphate }\end{array}$ & $\begin{array}{l}\text { Fructose-1,6- } \\
\text { diphosphate }\end{array}$ & Heptose & $\begin{array}{l}\text { Pentose-5- } \\
\text { phosphate }\end{array}$ & $\begin{array}{c}\text { Nucleotide } \\
\text { pentose }\end{array}$ & $\begin{array}{c}\text { Triose } \\
\text { phosphate }\end{array}$ & $\begin{array}{c}\text { Pyruvic } \\
\text { acid }\end{array}$ & $\begin{array}{l}\text { Lactic } \\
\text { acid }\end{array}$ \\
\hline Normal & $8.3 \pm 0.7$ & $3.6 \pm 0.4$ & $12.5 \pm 1.1$ & $2.4 \pm 0.4$ & $1.8 \pm 0.3$ & $380.8 \pm 18.6$ & $11.5 \pm 2.0$ & $9.3 \pm 1.0$ & $84.0 \pm 7.8$ \\
\hline Favic & $7.9 \pm 0.6$ & $3.8 \pm 0.4$ & $11.8 \pm 1.2$ & $2.1 \pm 0.5$ & $2.2 \pm 0.5$ & $396.4 \pm 20.3$ & $12.2 \pm 2.3$ & $9.8 \pm 1.2$ & $76.2 \pm 8.1$ \\
\hline
\end{tabular}

* Values reported represent means $\pm \mathrm{SE}$ of 10 determinations on normal subjects and 12 determinations on favic subjects. All values in $\mu$ moles $/ 100 \mathrm{ml} \mathrm{RBC} \mathrm{(packed} \mathrm{cell} \mathrm{volume).}$

removed, extracted with trichloracetic acid (10 per cent final concentration), filtered, and neutralized with $\mathrm{NaOH}$.

Chemical determinations. Glucose was determined by means of glucose oxidase (11); glucose-6-phosphate (G6P) and fructose-6-phosphate (F6P) by the spectrophotometric technique (12) without and with added phosphohexose isomerase; and F-1,6P and triosephosphate (TP) according to Slater (13) with and without added aldolase. Heptose was estimated by the cysteine- $\mathrm{H}_{2} \mathrm{SO}_{4}$ procedure (14); lactic acid by the Barker method (15); and total pentose and pentose-5-phosphate by a modified Bial's reaction (16).

Pyruvic acid was determined by means of lactate dehydrogenase (17), whereby the quantitative oxidation of DPNH was followed spectrophotometrically and lactate formation colorimetrically. The mixture contained per milliliter: $0.5 \mathrm{ml}$ of neutralized trichloroacetic acid extract (diluted if required) ; $0.1 \mathrm{ml}$ of $0.001 \mathrm{M} \mathrm{DPNH}$; $0.39 \mathrm{ml}$ of $0.25 \mathrm{M}$ glycylglycine buffer, $\mathrm{pH} 7.6 ; 0.01 \mathrm{ml}$ of lactate dehydrogenase. The mixture was either prepared in a spectrophotometer cuvet and the decrease in absorbance at $340 \mathrm{~m} \mu$ recorded, or incubated at $37^{\circ} \mathrm{C}$ for 1 hour and lactic acid determined thereafter by the usual method. Results were the same.

For nucleotide estimation the acid extract was adsorbed on Norite A. Pentose was redetermined on the filtrate by the orcinol reaction and the values for nucleotide pentose obtained by difference.

Calculations. For experiments with intact cells the results are expressed in micromoles per milliliter of the extracellular and intracellular water. The latter was assumed to be 65 per cent of the packed cell volume (18). The data reported are the means of nine experiments on favic subjects and eight on controls. Six experiments were performed on hemolysates from normal and favic subjects. The mean values reported correspond to $1 \mathrm{ml}$ of intact red blood cells.

Reagents. Glucose was a product of Merck and Co.;

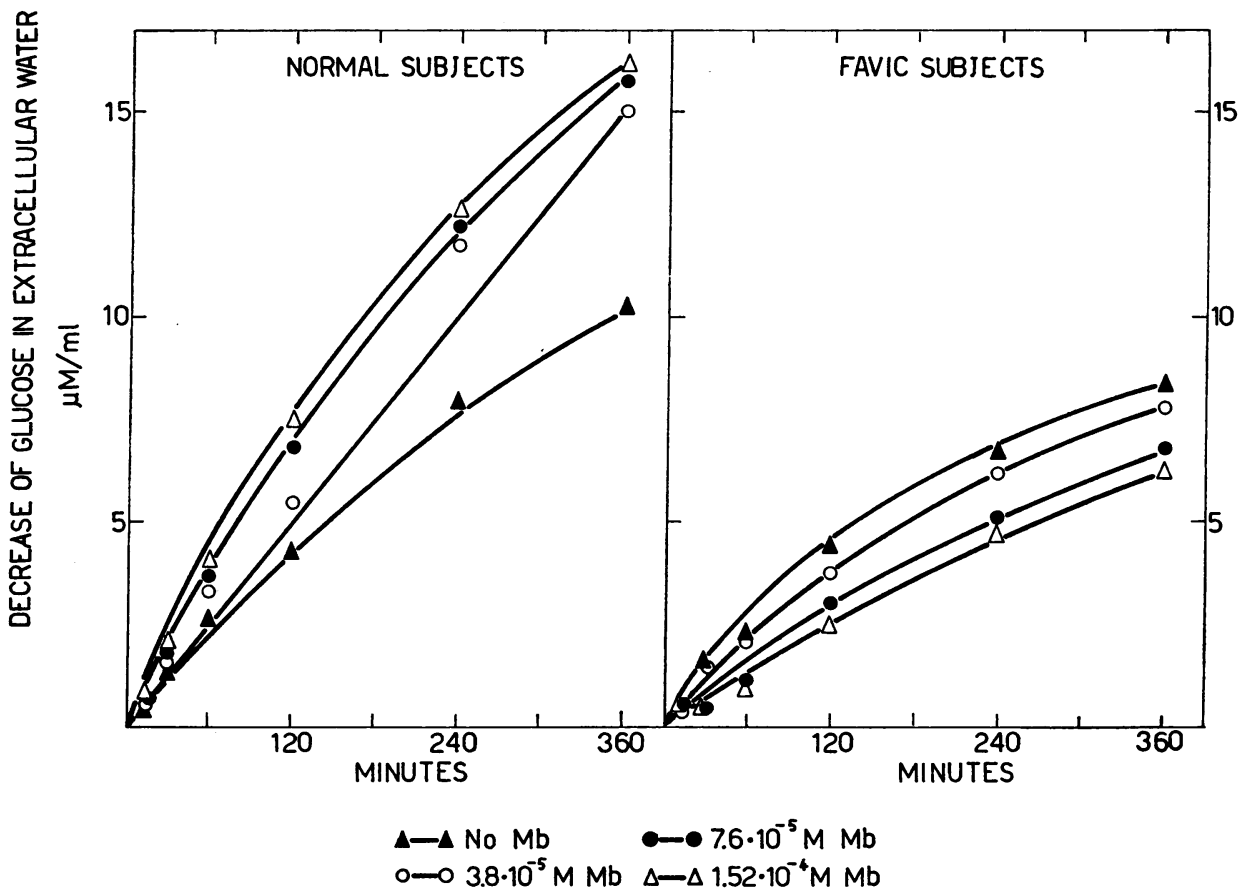

Fig. 1. GLUCOSE UPTAKe BY SUSPENSIONS OF RED BLOOD CELlS FROM NORMAL AND FAVA BEANSENSITIVE sUBJECTS. Assay mixture as in Table II. 


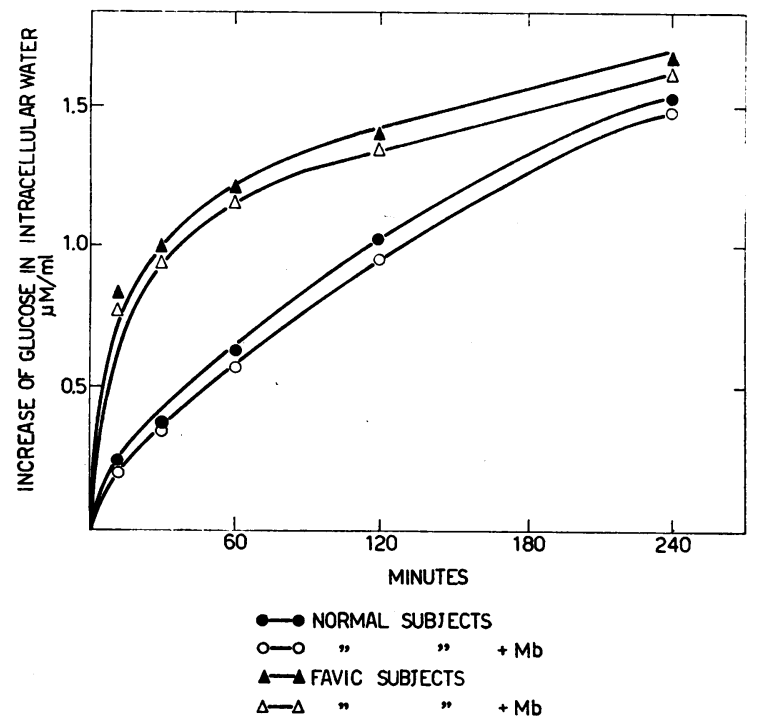

Fig. 2. Free glucose accumulation IN RED blood CELLS FROM NORMAL AND FAVA BEAN-SENSITIVE SUBJECTS. Assay mixture as in Table II. In experiments with $\mathrm{Mb}$ its final concentration was $3.8 \times 10^{-5} \mathrm{M}$.

F-1,6P (sodium salt) and DPN were purchased from the Sigma Chemical Co. All enzymes used for spectrophotometric determination were products of Biochemica Boehringer.

\section{RESULTS}

Concentration of metabolites. The data concerning concentrations of some metabolites $( \pm \mathrm{SE})$ in normal and favic RBC are reported in Table I. No significant difference is found between the two groups with respect to these compounds, which, determined throughout incubation, account for about 100 per cent of the carbon transformed.

Glucose metabolism by suspensions of red blood cells. Glucose uptake by normal and favic RBC suspensions at increasing concentrations of Methylene blue is shown in Figure 1. In the absence of $\mathrm{Mb}$, glucose disappearance from the medium is only slightly decreased in experiments with abnormal as compared with normal cells. When the dye is added, glucose uptake by the normal RBC increases progressively, as described by Brin and Yonemoto (19), whereas in the favic cells a "paradoxical" inhibition is found.

On the other hand, if we turn to the intracellular glucose concentration (see Figure 2) we can see that, whereas $\mathrm{Mb}$ is ineffective, the initial accumulation rate of the free sugar is considerably higher in favic cells : at 30 minutes' incubation the amount is increased about fourfold. In this figure and in Tables II-VI Mb concentration was $3.8 \times 10^{-5} \mathrm{M}$.

In striking contrast to free glucose, the concentration of G6P and F6P never increased during incubation; on the contrary, a depletion with respect to the values at zero time was often observed. Glucose phosphorylation seems therefore to be the limiting step in glucose utilization by $\mathrm{RBC}$ suspensions.

The data concerning free ${ }^{1}$ and nucleotide pen-

${ }^{1}$ In experiments in which both total pentose and pentose-5-phosphate were determined, the values have always been equal; the former was omitted thereafter.

TABLE II

Pentose phosphate and heptose synthesis in normal erythrocytes *

\begin{tabular}{|c|c|c|c|c|c|c|}
\hline \multirow{2}{*}{$\begin{array}{c}\text { Incubation } \\
\text { time }\end{array}$} & \multicolumn{2}{|c|}{ Pentose-5-phosphate } & \multicolumn{2}{|c|}{ Nucleotide pentose } & \multicolumn{2}{|c|}{ Heptose } \\
\hline & Without $\mathrm{Mb}$ & With $\mathrm{Mb} \dagger$ & Without $\mathrm{Mb}$ & With Mbt & Without $\mathrm{Mb}$ & With Mb† \\
\hline & \multicolumn{6}{|c|}{ umoles $/ \mathrm{ml}$ intracellular water $\S$} \\
\hline $\begin{array}{c}10 \mathrm{~min} \\
30 \mathrm{~min} \\
1 \mathrm{hr} \\
2 \mathrm{hr} \\
4 \mathrm{hr} \\
6 \mathrm{hr}\end{array}$ & $\begin{array}{l}0.28 \\
0.42 \\
0.65 \\
0.78 \\
1.52 \\
1.65\end{array}$ & $\begin{array}{l}0.70 \\
1.36 \\
1.70 \\
2.80 \\
3.92 \\
4.12\end{array}$ & $\begin{array}{l}0 \\
0 \\
0.11 \\
0.25 \\
0.35 \\
0.52\end{array}$ & $\begin{array}{l}0 \\
0 \\
0.20 \\
0.29 \\
0.40 \\
0.54\end{array}$ & $\begin{array}{l}0.01 \\
0.04 \\
0.04 \\
0.02 \\
0 \\
0\end{array}$ & $\begin{array}{l}0.07 \\
0.22 \\
0.33 \\
0.45 \\
0.66 \\
0.72\end{array}$ \\
\hline
\end{tabular}

* The incubation mixture contained per $\mathrm{ml}: 10 \mu$ moles of glucose; $30 \mu$ moles of phosphate buffer, $\mathrm{pH} 7.4 ; 0.43 \mathrm{ml}$ of $\mathrm{RBC}$ (packed cell volume). The reaction vessel was incubated at $37^{\circ} \mathrm{C}$ with shaking. A 10 -minute preincubation was performed before glucose addition, in order to insure temperature equilibration. Values reported are means of at least 6 experiments.

$\dagger$ Final concentration, $3.8 \times 10^{-5} \mathrm{M}$.

\pm Nucleotide pentose synthesis was statistically significant: $p<0.05$ at 1 hour and $<0.001$ afterward.

$\$$ Intracellular water was assumed to be 64 per cent of the packed cell volume. 
TABLE III

Pentose phosphate and heptose synthesis in favic erythrocytes *

\begin{tabular}{|c|c|c|c|c|c|c|}
\hline \multirow{2}{*}{$\underset{\text { time }}{\text { Incubation }}$} & \multicolumn{2}{|c|}{ Pentose 5-phosphate } & \multicolumn{2}{|c|}{ Nucleotide pentose } & \multicolumn{2}{|c|}{ Heptose } \\
\hline & $\overline{\text { Without } \mathbf{M b}}$ & $\overline{\text { With } \mathbf{M b}}$ & Without $\mathbf{M b}$ & With $\mathbf{M b}$ & Without $\mathbf{M b}$ & With Mb \\
\hline & \multicolumn{6}{|c|}{$\mu m o l e s / m l$ intracellular water } \\
\hline $\begin{array}{l}10 \mathrm{~min} \\
30 \mathrm{~min} \\
1 \mathrm{hr} \\
2 \mathrm{hr} \\
4 \mathrm{hr} \\
6 \mathrm{hr}\end{array}$ & $\begin{array}{l}0.27 \\
0.40 \\
0.68 \\
0.88 \\
1.48 \\
1.87\end{array}$ & $\begin{array}{l}0.31 \\
0.48 \\
0.73 \\
0.95 \\
1.50 \\
2.00\end{array}$ & $\begin{array}{l}0 \\
0 \\
0.10 \\
0.22 \\
0.42 \\
0.58\end{array}$ & $\begin{array}{l}0 \\
0 \\
0.12 \\
0.20 \\
0.45 \\
0.61\end{array}$ & $\begin{array}{l}0 \\
0.03 \\
0.03 \\
0.03 \\
0 \\
0\end{array}$ & $\begin{array}{l}0 \\
0.03 \\
0.03 \\
0.04 \\
0.03 \\
0\end{array}$ \\
\hline
\end{tabular}

* Conditions and other indications are as in Table II.

tose, as well as heptulose synthesis, are summarized in Tables II and III.

No difference can be detected between the two groups of subjects in the absence of $\mathrm{Mb}$. The formation of pentose and heptulose, which takes place in the normal erythrocyte mainly through the oxidative pathway (20), proceeds at a normal rate in the sensitive cells; the impaired function of the oxidative shunt is apparently compensated completely in this respect, as previously demonstrated $(9,10)$, by the high transketolase (TK) and transaldolase (TA) activities, which bring about the synthesis of the same compounds by means of nonoxidative reactions. This mechanism, however, is unaffected by $\mathrm{Mb}$, which actually stimulates pentose and heptulose formation in normal, but not in favic, red blood cells.

In Table IV the pattern of $\mathrm{F}-1,6 \mathrm{P}$ and $\mathrm{TP}$ concentration is reported. Two features seem of interest: 1) In the absence of $\mathrm{Mb}$ both sugars accumulate in the cells during the first hour of incubation, and disappear thereafter; 2) when the dye is added, $\mathrm{F}-1,6 \mathrm{P}$ and $\mathrm{TP}$ invariably become undetectable. No explanation is offered so far for point 1 ; point 2 is discussed below.

Pyruvic and lactic acid have been determined both in the cells and in the supernatant fluid of the reaction mixture. The values obtained are shown in Tables V and VI.

The time course of pyruvate synthesis is similar in normal and favic cells and is accelerated by $\mathrm{Mb}$. At all incubation times after 10 minutes, extracellular pyruvate is in higher concentration than is intracellular pyruvate. Lactic acid behaves in a similar way, although the concentration difference is smaller and delayed in time. Lactate synthesis in favic RBC is slightly lower than in normal cells. The different concentration of both compounds in the extracellular and intracellular water still awaits a full explanation.

As a check of our follow-up of glucose fate during erythrocyte glycolysis we have reported the carbon recovery values in Table VII. The values shown are the ratios between the sum of carbon microatoms recovered at each incubation time as $\mathrm{F}-1,6 \mathrm{P}, \mathrm{TP}$, pentose, heptulose, pyru-

TABLE IV

Fructose-1,6-diphosphate and triose phosphate synthesis in normal and favic erythrocytes *

\begin{tabular}{|c|c|c|c|c|c|c|c|c|}
\hline \multirow{3}{*}{$\begin{array}{c}\text { Incubation } \\
\text { time }\end{array}$} & \multicolumn{4}{|c|}{ Normal subjects } & \multicolumn{4}{|c|}{ Favic subjects } \\
\hline & \multicolumn{2}{|c|}{$\begin{array}{c}\text { Fructose-1,6- } \\
\text { diphosphate }\end{array}$} & \multicolumn{2}{|c|}{ Triose phosphate } & \multicolumn{2}{|c|}{$\begin{array}{c}\text { Fructose-1,6- } \\
\text { diphosphate }\end{array}$} & \multicolumn{2}{|c|}{ Triose phosphate } \\
\hline & Without $\mathbf{M b}$ & With $\mathbf{M b}$ & Without $\mathbf{M b}$ & With $\mathbf{M b}$ & Without $\mathbf{M b}$ & With $\mathrm{Mb}$ & Without $\mathbf{M b}$ & With $\mathbf{M b}$ \\
\hline & \multicolumn{8}{|c|}{ umoles/ml intracellular water } \\
\hline $\begin{array}{c}10 \mathrm{~min} \\
30 \mathrm{~min} \\
1 \mathrm{hr} \\
2 \mathrm{hr} \\
4 \mathrm{hr} \\
6 \mathrm{hr}\end{array}$ & $\begin{array}{l}0.09 \\
0.25 \\
0.39 \\
0.25 \\
0 \\
0\end{array}$ & $\begin{array}{l}0.02 \\
0.03 \\
0.04 \\
0.01 \\
0 \\
0\end{array}$ & $\begin{array}{l}0.16 \\
0.73 \\
0.83 \\
0.42 \\
0.03 \\
0\end{array}$ & $\begin{array}{l}0.06 \\
0.08 \\
0.08 \\
0 \\
0 \\
0\end{array}$ & $\begin{array}{l}0.09 \\
0.29 \\
0.39 \\
0.30 \\
0.09 \\
0\end{array}$ & $\begin{array}{l}0 \\
0 \\
0.02 \\
0 \\
0 \\
0\end{array}$ & $\begin{array}{l}0.15 \\
0.52 \\
0.89 \\
0.73 \\
0.02 \\
0\end{array}$ & $\begin{array}{l}0 \\
0 \\
0 \\
0.03 \\
0 \\
0\end{array}$ \\
\hline
\end{tabular}

* Conditions and other indications are as in Table II. 
TABLE V

Pyruvate synthesis in normal and favic eyrthrocytes *

\begin{tabular}{|c|c|c|c|c|c|c|c|c|}
\hline \multirow{3}{*}{$\begin{array}{c}\text { Incubation } \\
\text { time }\end{array}$} & \multicolumn{4}{|c|}{ Normal subjects } & \multicolumn{4}{|c|}{ Favic subjects } \\
\hline & \multicolumn{2}{|c|}{$\begin{array}{c}\text { Extracellular } \\
\text { pyruvate }\end{array}$} & \multicolumn{2}{|c|}{$\begin{array}{c}\text { Intracellular } \\
\text { pyruvate }\end{array}$} & \multicolumn{2}{|c|}{$\begin{array}{c}\text { Extracellular } \\
\text { pyruvate }\end{array}$} & \multicolumn{2}{|c|}{$\begin{array}{c}\begin{array}{c}\text { Intracellular } \\
\text { pyruvate }\end{array} \\
\end{array}$} \\
\hline & Without $\mathbf{M b}$ & With Mb & Without Mb & With Mb & Without $\mathrm{Mb}$ & With $\mathbf{M b}$ & Without $\mathbf{M b}$ & With $\mathrm{Mb}$ \\
\hline & \multicolumn{2}{|c|}{ umoles $/ \mathrm{ml}$} & \multicolumn{2}{|c|}{ Mmoles $/ \mathrm{ml}$} & \multicolumn{2}{|c|}{$\mu$ moles $/ \mathrm{ml}$} & \multicolumn{2}{|c|}{ umoles $/ \mathrm{ml}$} \\
\hline $10 \mathrm{~min}$ & 0.03 & 0.28 & 0.02 & 0.04 & 0.03 & 0.30 & 0.02 & 0.03 \\
\hline $30 \mathrm{~min}$ & 0.08 & 0.46 & 0.04 & 0.10 & 0.07 & 0.52 & 0.03 & 0.09 \\
\hline $1 \mathrm{hr}$ & 0.22 & 0.75 & 0.07 & 0.13 & 0.19 & 0.63 & 0.08 & 0.12 \\
\hline $2 \mathrm{hr}$ & 0.30 & 0.70 & 0.10 & 0.15 & 0.31 & 0.75 & 0.11 & 0.16 \\
\hline $4 \mathrm{hr}$ & 0.45 & 1.40 & 0.13 & 0.20 & 0.43 & 1.32 & 0.12 & 0.19 \\
\hline $6 \mathrm{hr}$ & 0.66 & 1.65 & 0.14 & 0.22 & 0.64 & 1.56 & 0.15 & 0.21 \\
\hline
\end{tabular}

* Conditions and other indications as in Table II.

vic and lactic acid, and the glucose carbon microatoms disappeared at the same time.

It is clearly seen that in the absence of $\mathrm{Mb}$, in normal as well as in favic RBC, the compounds determined account for the whole of the glucose uptake; there is no "carbon leakage." Addition of the dye, by stimulating the oxidative pathway, brings about $\mathrm{CO}_{2}$ evolution in normal cells, and the carbon recovery values are thus lowered; the behavior of abnormal cells remains unaffected because of the G6PD deficiency.

$F-1,6 P$ metabolism in hemolysates. The action described above of $\mathrm{Mb}$ on $\mathrm{F}-1,6 \mathrm{P}$ and $\mathrm{TP}$ synthesis, as well as the pyruvate to lactate ratios, suggested a possible effect of the dye on TP oxidation. This was tested on hemolyzed cells, which were incubated with F-1,6P in an arsenolytic system; at given times the diester consumption and the TP, pyruvate, and lactate formed were estimated.

The figures obtained were linear with time in each experiment. In Figure 3 the 60-minute values concerning normal and favic cases are plotted as a function of $\mathrm{Mb}$ concentration, varying from 1.2 to $12 \times 10^{-5} \mathrm{M}$. It is clearly seen that in normal hemolysates the dye enhances F-1,6P breakdown as well as pyruvate and lactate formation. In favic hemolysates the amount of $F-1,6 \mathrm{P}$ metabolized is decreased. At a low concentration $\mathrm{Mb}$ addition results in a slight activation of $\mathrm{TP}$ conversion into pyruvate and lactate, F-1,6P consumption being unaffected. At higher concentrations an inhibitory effect is observed.

\section{DISCUSSION}

The data presented seem to give some insight into the different characteristic features of glucose metabolism in favic red blood cells as compared with normal cells. Whereas in the absence of $\mathrm{Mb}$ only a slight decrease in the sugar consumption is found, addition of the dye results in definitely different patterns in the two kinds of cells. In normal RBC glucose uptake increases as a function of $\mathrm{Mb}$ concentration, whereas in favic

TABLE VI

Lactate synthesis in normal and favic erythrocytes *

\begin{tabular}{|c|c|c|c|c|c|c|c|c|}
\hline \multirow{3}{*}{$\begin{array}{c}\text { Incubation } \\
\text { time }\end{array}$} & \multicolumn{4}{|c|}{ Normal subjects } & \multicolumn{4}{|c|}{ Favic subjects } \\
\hline & \multicolumn{2}{|c|}{$\begin{array}{c}\text { Extracellular } \\
\text { lactate }\end{array}$} & \multicolumn{2}{|c|}{$\begin{array}{l}\text { Intracellular } \\
\text { lactate }\end{array}$} & \multicolumn{2}{|c|}{$\begin{array}{l}\text { Extracellular } \\
\text { lactate }\end{array}$} & \multicolumn{2}{|c|}{$\begin{array}{c}\text { Intracellular } \\
\text { lactate }\end{array}$} \\
\hline & Without $\mathbf{M b}$ & With $\mathbf{M b}$ & Without $\mathbf{M b}$ & With Mb & Without Mb & With $\mathbf{M b}$ & Without $\mathbf{M b}$ & With Mb \\
\hline $10 \mathrm{~min}$ & \multicolumn{2}{|l|}{ smole. } & \multicolumn{2}{|l|}{$\boldsymbol{\mu m}$} & \multicolumn{2}{|l|}{$\mu m$} & \multicolumn{2}{|l|}{$\boldsymbol{\mu} \boldsymbol{n}$} \\
\hline $10 \mathrm{~min}$ & 0.30 & $\begin{array}{l}0.51 \\
1.22\end{array}$ & 0.44 & 0.56 & 0.32 & 0.31 & 0.24 & 0.20 \\
\hline $1 \mathrm{hr}$ & 2.00 & 3.02 & 1.21 & 1.40 & 1.38 & 1.00 & 0.81 & 0.18 \\
\hline $2 \mathrm{hr}$ & 529 & 5.53 & 1.72 & 1.06 & 425 & 418 & 1.11 & $\begin{array}{l}0.01 \\
142\end{array}$ \\
\hline $4 \mathrm{hr}$ & 11.25 & 12.52 & 2.78 & 2.00 & $\begin{array}{l}4.23 \\
8.50\end{array}$ & $\begin{array}{l}4.10 \\
825\end{array}$ & 2.16 & 1.42 \\
\hline $6 \mathrm{hr}$ & 14.65 & 15.31 & 5.21 & 5.47 & 13.50 & 12.75 & 4.30 & 4.48 \\
\hline
\end{tabular}

* Conditions and other indications as in Table II. 
$\mathrm{RBC}$ not only the usual catalytic activity fails, but an inhibitory effect appears. This has been described by Tarlov (21) in RBC from primaquinesensitive subjects.

These findings may be interpreted fairly simply. It has been well known for many years that $\mathrm{Mb}$ stimulates oxygen uptake by the red cell $(22,23)$. It can now be stated that in normal cells $\mathrm{Mb}$ acts as an activator of the reoxidation of reduced triphosphopyridine nucleotide, formed by G6PD and 6-phosphogluconic dehydrogenase activities; this leads to an increased oxidative formation of pentulose phosphate, which in turn is recycled to $\mathrm{G} 6 \mathrm{P}$ via $\mathrm{TK}$ and TA (see reference 24 ). Incomplete recovery of added carbon (owing to $\mathrm{CO}_{2}$ evolution) and higher concentrations of some metabolites (like pentose phosphate and heptulose phosphate) are consistent with this interpretation, which is in agreement with findings of other authors $(19,25)$.

In favic cells the catalytic action of $\mathrm{Mb}$ fails, owing to lack of G6PD, and neither the synthesis of pentose and heptulose is enhanced, nor does the carbon leakage as $\mathrm{CO}_{2}$ become apparent. ${ }^{2}$

2 After this paper had been submitted a report appeared (J. Lab. clin. Med. 1961, 58, 715) in which experiments with erythrocytes from primaquine-sensitive subjects are described. In these cells also, pentose fails to accumulate in the presence of glucose and $\mathrm{Mb}$.
TABLE VII

Recovery of added carbon during glucose metabolism in $R B C$ suspensions from normal and favic subjects *

\begin{tabular}{|c|c|c|c|c|}
\hline \multirow[b]{3}{*}{$\begin{array}{l}\text { Incubation } \\
\text { time }\end{array}$} & \multicolumn{4}{|c|}{ Per cent carbon recovery $\dagger$} \\
\hline & \multicolumn{2}{|c|}{ Normal subjects } & \multicolumn{2}{|c|}{ Favic subjects } \\
\hline & $\begin{array}{l}\text { Without } \\
\text { Mb }\end{array}$ & $\begin{array}{l}\text { With } \\
\text { Mb }\end{array}$ & $\begin{array}{l}\text { Without } \\
\text { Mb }\end{array}$ & $\begin{array}{l}\text { With } \\
\text { Mb }\end{array}$ \\
\hline $10 \mathrm{~min}$ & 104 & 86 & 105 & 98 \\
\hline $30 \mathrm{~min}$ & 99 & 82 & 102 & 98 \\
\hline $1 \mathrm{hr}$ & 103 & 85 & 99 & 98 \\
\hline $2 \mathrm{hr}$ & 105 & 80 & 101 & 99 \\
\hline $4 \mathrm{hr}$ & 96 & 79 & 101 & 99 \\
\hline $6 \mathrm{hr}$ & 98 & 76 & 104 & 96 \\
\hline
\end{tabular}

* Conditions and other indications as in Table II.

t Per cent ratio between microatoms of carbon recovered in the metabolites determined and microatoms of carbon in the glucose, which has disappeared.

These results could be approximately anticipated on the grounds of previous knowledge.

Further consideration of the experimental data suggests that a coenzyme-linked activation is exerted by $\mathrm{Mb}$ not only at the G6P, but also at the triose phosphate level, and this holds true for favic as well as for normal cells. This effect could explain the higher removal rate of $\mathrm{F}-1,6 \mathrm{P}$ and TP (which are assumed to be in aldolase and TP isomerase equilibrium, respectively) in intact erythrocytes, and has been reproduced clearly in a soluble hemolyzed system, where the reoxidation

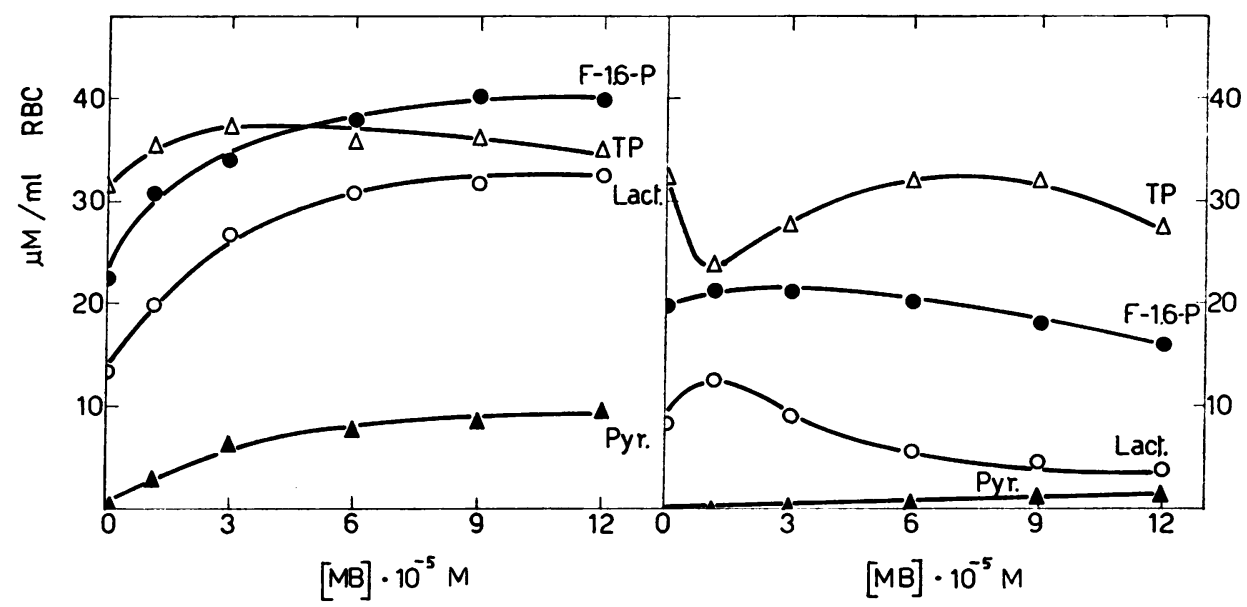

Fig. 3. EFFECT OF METh YLENE BLUE ON FRUCTOSE-1,6-DiPHOSPHATE BREAKDOWN IN HEMOLYSATES FROM NORMAL AND FAVA BEAN-SENSITIVE RED BLOOD CELLS. The assay mixture contained per $\mathrm{ml}: 3 \mu$ moles of $\mathrm{F}-1,6 \mathrm{P}, 25 \mu$ moles of $\mathrm{pH} 7.4$ glycylglycine buffer, $15 \mu$ moles of nicotinic amide, $50 \mu$ moles of $\mathrm{Na}_{3} \mathrm{AsO}_{4}, 3 \mu$ moles of $\mathrm{MgSO}_{4}, 0.10 \mu$ mole of DPN, $0.1 \mathrm{ml}$ of hemolyzed cells corresponding to $0.03 \mathrm{ml}$ of $\mathrm{RBC}$, and $\mathrm{Mb}$ at the concentration indicated. Lact. refers to lactic acid and Pyr. to pyruvic acid. Left, normal RBC. Right, fava bean-sensitive RBC. The curve marked F-1,6-P represents breakdown values. 


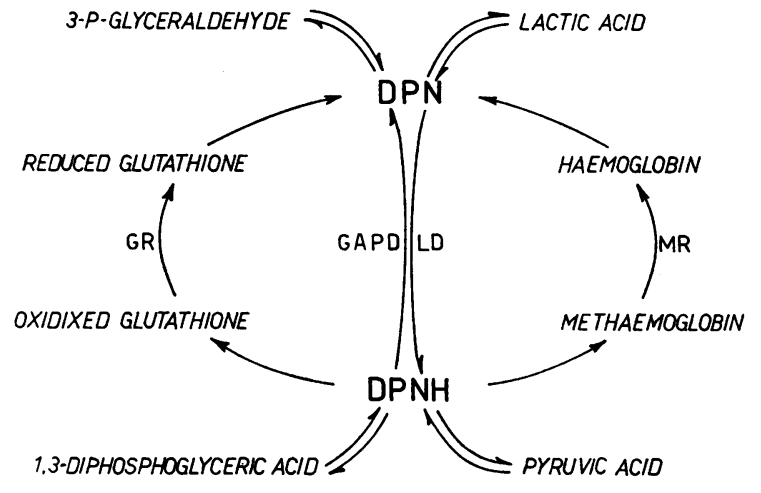

Fig. 4. Pathways of DIPHOSPhopyridine NUCleotide OXIDATION AND REDUCTION IN THE RED CELL. GR: glutathione reductase; GAPD, phosphoglyceraldehyde dehydrogenase; LD, lactate dehydrogenase; MR, methemoglobin reductase. The last is the only $\mathrm{Mb}$-sensitive system.

of the dehydrogenase-formed DPNH was the limiting step for TP metabolism. Three systems are known to oxidize DPNH in RBC: 1) lactic dehydrogenase, 2) glutathione reductase, and 3) methemoglobin reductase (see Figure 4). The last is better defined as a diaphorase which may use DPNH or TPNH as hydrogen donor and methemoglobin, cytochrome $\mathrm{C}$ or $\mathrm{O}_{2}$ as acceptor (26). Besides, methemoglobin reductase differs from the other two in that it is $\mathrm{Mb}$-sensitive, and this could explain the action of the dye. It may be recalled here that Stumpf (27) observed in plant tissues that $\mathrm{Mb}$ could replace pyruvate or acetic aldehyde as a DPN-coupled diaphorase activator during F-1,6P breakdown, whereas Wendel (28) reported in 1929 the Mb catalysis of lactate oxidation to pyruvate in RBC. As may be seen in Tables V and VI and Figure 3, we have found accordingly that the effect of $\mathrm{Mb}$ appears to be much more pronounced when pyruvate rather than lactate accumulation is considered. Furthermore, other experiments (29) have indicated that DPNH and TPNH oxidation, like TP oxidation, undergoes a concentrationdependent stimulation by $\mathrm{Mb}$.

The evidence presented supports the conclusion that failure of $\mathrm{F}-1,6 \mathrm{P}$ and $\mathrm{TP}$ to accumulate in the erythrocytes during glucose consumption in the presence of $\mathrm{Mb}$ is due to the ability of the latter to act as a carrier between $\mathrm{DPNH}$ and $\mathrm{O}_{2}$. Contrary to the G6PD-linked effect, this action is also found in cells from favic subjects, at a concentration of $1.2 \times 10^{-5} \mathrm{M}$; however, it is less pronounced, presumably because of a reduced diaphorase activity (8). As to the inhibition observed at higher dye concentrations, no explanation can be offered at the moment; we can only note that it is analogous to the effect exhibited on glucose uptake.

The free glucose concentration in the erythrocyte is a function both of entry rate and of utilization rate. The finding of a higher intracellular glucose concentration in favic cells as compared with the normal is leading us to a closer consideration of the sugar transport process, which might well be involved in the peculiar abnormality of favic RBC. Studies are now in progress in our laboratory concerning the entry pattern of various metabolizable and nonmetabolizable monosaccharides in normal and favic red cells.

\section{SUM MARY}

1. Glucose metabolism in intact normal and favic red cells has been studied by means of estimation of intracellular and extracellular concentrations of various metabolites during incubation.

2. In normal cells the addition of methylene blue brings about a change in the metabolite pattern, characteristic of a high operation rate of the hexose monophosphate oxidation pathway. This fails in the favic cells where, on the contrary, some inhibition of glucose uptake appears at high concentrations of dye.

3. Experiments with hemolyzed cells have shown that methylene blue increases the rate of breakdown of triose phosphate in favic as well as in normal erythrocytes. This explains some findings on intact cells, and the evidence presented points to a stimulated reoxidation of reduced diphosphopyridine nucleotide as the mechanism of this effect of the dye.

4. In spite of lower glucose consumption, the intracellular glucose concentration throughout incubation is always higher in favic than in normal cells.

5. The results are discussed in relation to the present knowledge of favic cell metabolism and the action of methylene blue.

\section{REFERENCES}

1. Beutler, E., Dern, R. J., Flanagan, C. L., and Alving, A. S. The hemolytic effect of primaquine. VII. 
Biochemical studies of drug-sensitive erythrocytes. J. Lab. clin. Med. 1955, 45, 286.

2. Beutler, E. In vitro studies of the stability of red cell glutathione: A new test for drug sensitivity (abstract). J. clin. Invest. 1956, 35, 690.

3. Carson, P. E., Flanagan, C. L., Ickes, C. E., and Alving, A. S. Enzymatic deficiency in primaquinesensitive erythrocytes. Science 1956, 124, 484.

4. Gross, R. T., Hurwitz, R. E., and Marks, P. A. An hereditary enzymatic defect in erythrocyte metabolism: Glucose-6-phosphate dehydrogenase deficiency. J. clin. Invest. 1958, 37, 1176.

5. Sansone, G., and Segni, G. Prime determinazioni del glutatione (GSH) ematico nel favismo. Boll. Soc. ital. Biol. sper. 1956, 32, 456.

6. Sansone, G., and Segni, G. Nuovi aspetti dell'alterato biochimismo degli eritrociti di favici : Assenza pressoche' completa della glucoso-6-P deidrogenasi, Boll. Soc. ital. Biol. sper. 1958, 34, 327.

7. Bonsignore, A., Fornaini, G., Segni, G., and Seitun, A. Comportamento di alcuni enzimi eritrocitari di un soggetto favico nel periodo post-emolitico. Boll. Soc. ital. Biol. sper. 1960, 36, 1215.

8. Bonsignore, A., Fornaini, G., Segni, G., and Fantoni, A. Glutathione-reductase and methemoglobin-reductase in erythrocytes of human subjects with a case history of favism. Ital. J. Biochem. 1960, 9. 345.

9. Bonsignore, A., Fornaini, G., Segni, G., and Fantoni, A. Biosynthesis of pyridine coenzymes in erythrocytes from subjects with favism history. Ital. J. Biochem. 1961, 10, 212.

10. Bonsignore, A., Fornaini, G., Segni, G., and Seitun, A. Transketolase and transaldolase reactions in the erythrocytes of human subjects with favism history. Biochem. biophys. Res. Com. 1961, 4, 147.

11. Kaplan, N. O. Enzymatic determination of free sugars in Methods in Enzymology, S. P. Colowick and N. O. Kaplan, Eds. New York, Academic Press, 1957, vol. 3, p. 107.

12. Horecker, B. L., and Wood, W. A. D-glucose-6phosphate. Ibid., p. 152.

13. Slater, E. C. Spectrophotometric determination of fructose-1: 6-diphosphate, hexosemonophosphates, adenosinetriphosphate and adenosinediphosphate. Biochem. J. 1953, 53, 157.

14. Dische, Z. Qualitative and quantitative colorimetric determination of heptoses. J. biol. Chem. 1953, 204, 983.
15. Barker, S. B. Preparation and colorimetric determination of lactic acid in Methods in Enzymology, S. P. Colowick and N. O. Kaplan, Eds. New York, Academic Press, 1957, vol. 3, p. 241.

16. Bonsignore, A., Conte, G., and Orunesu, M. Determination of pentose-5-phosphate in the presence of other pentoses. G. Biochim. 1952, 1, 383.

17. Meister, A. Crystalline lactate dehydrogenase in Biochemical Preparations, E. G. Ball, Ed. New York, Wiley, 1952, vol. 2, p. 18.

18. Wintrobe, M. M. Clinical Hematology, 4th ed. Philadelphia, Lea \& Febiger, 1956.

19. Brin, M., and Yonemoto, R. H. Stimulation of the glucose oxidative pathway in human erythrocytes by methylene blue. J. biol. Chem. 1958, 230, 307.

20. Hiatt, H. H., and Laureau, J. Studies of ribose metabolism. VIII. Pathways of ribose biosynthesis in vivo and in vitro in rat, mouse, and human tissues. J. biol. Chem. 1960, 235, 1241.

21. Tarlov, A. R. quoted by Carson, P. E. Glucose-6phosphate dehydrogenase deficiency in hemolytic anemia. Fed. Proc. 1960, 19, 995.

22. Harrop, G. A., Jr., and Barron, E. S. G. Studies on blood cell metabolism. I. The effect of methylene blue and other dyes upon the oxygen consumption of mammalian and avian erythrocytes. J. exp. Med. 1928, 48, 207.

23. Moruzzi, G. Sul problema della posizione della glicolisi rispetto alla ossidazione del glucosio. Azione del monoiodacetato sodico sulla catalisi da blu di metilene. Arch. Sci. biol. (Bologna) 1936, 22, 1.

24. Bonsignore, A. Carbohydrate interconversion reactions and their significance in intermediary metabolism. Lecture held at the Quintas Jornadas Bioquimicas Latinas, Barcelona, May 1959.

25. Szeinberg, A., and Marks, P. A. Substances stimulating glucose catabolism by the oxidative reactions of the pentose phosphate pathway in human erythrocytes. J. clin. Invest. 1961, 40, 914.

26. Huennekens, F. M., Caffrey, R. W., Basford, R. E., and Gabrio, B. W. Erythrocyte metabolism. IV. Isolation and properties of methemoglobin reductase. J. biol. Chem. 1957, 227, 261.

27. Stumpf, P. K. Carbohydrate metabolism in higher plants. III. Breakdown of fructose diphosphate by pea extracts.. J. biol. Chem. 1950, 182, 261.

28. Wendel, W. B. Proc. Soc. exp. Biol. (N. Y.) 1929, 26, 865, quoted by Prankerd, T. A. J. in The Red Cell. Oxford, Blackwell, 1961, p. 81.

29. Leoncini, G., and Fornaini, G. Unpublished results. 